Original Research Paper

\title{
Histopathological of Brain, Eye, Liver, Spleen Organs of Grouper Suspected VNN in Penyambuan Village, North Lombok
}

\author{
Agustina Rahmawanti ${ }^{1 *}$, Dewi Nur'aini Setyowati ${ }^{1}$, Alis Mukhlis ${ }^{1}$ \\ ${ }^{1}$ Department of Fisheries and Marine Science, Mataram University, Mataram, Indonesia
}

\author{
Article History \\ Received : January $07^{\text {th }}, 2021$ \\ Revised : January $15^{\text {th }}, 2021$ \\ Accepted : January $19^{\text {th }}, 2021$ \\ Published : January $25^{\text {th }}, 2021$ \\ *Corresponding Author: \\ Agustina Rahmawanti, \\ Department of Fisheries and \\ Marine Science, Mataram \\ University, Mataram, Indonesia; \\ email: \\ Agustinarahma64@gmail.com
}

\begin{abstract}
Cantang grouper is one of the leading NTB commodities that have high economic value. Cantang grouper (Epinephelus fuscoguttatus) has a wide distribution, one of which is in Penyambuan Village, North Lombok Regency. The disease that often attacks grouper fish is VNN (Viral Nervous Necrosis). One of the methods that can be used to detect VNN is the histopathological method. The purpose of this study was to determine the suspected cases and levels of infection with the VNN (Viral Nervous Necrosis) virus in grouper fish (Epinephelus fuscoguttatus) cultivated in Penyambuan Hamlet, Tanjung District, North Lombok Regency by using the histopathological method. The research method used is descriptive by explaining the results obtained from the histopathological test of 3 samples taken by looking at the presence or absence of necrosis in the eye and brain organs of the test sample. The results of observations using a microscope on the test sample after the histopathological process showed that the second sample (S2) of cantang grouper from the KJA in Pemambuan was suspected to be positive for VNN infection, as seen from the presence of necrosis in the form of vacuoles in the brain and eye organs in the level of chronic infection. From the results of this study, it is suggested that further research be carried out in the form of confirmation of the results using a more accurate method, namely real-time PCR. This study can serve as a detection guide for samples of suspected VNN.
\end{abstract}

Keywords: Cantang Grouper, VNN, Histopathology

\section{Pendahuluan}

Nusa Tenggara Barat merupakan provinsi yang memiliki potensi budidaya perikanan yang tinggi dilihat dari kawasan pantai, laut, danau dan kawasan perairan lainnya yang dapat dimanfaatkan sebagai media budidaya. Beberapa jenis biota yang menjadi komoditas budidaya perikanan Nusa Tenggara Barat (NTB) adalah udang, ikan, teripang, kerang dan rumput laut. Salah satu jenis ikan yang memiliki prospek pengembangan yang baik adalah ikan kerapu. Nusa Tenggara Barat (NTB) memiliki banyak daerah berpotensi untuk membudidayakan ikan kerapu, contohnya adalah Dusun Penyambuan, Desa Jenggala, Kecamatan Tanjung, Kabupaten Lombok Utara. Dusun Penyambuan merupakan kawasan budidaya ikan kerapu dimana jenis kerapu yang dibudidayakan adalah ikan kerapu cantang. Berbagai literatur telah melaporkan bahwa virus masih menjadi patogen penyebab penyakit pada ikan yang dibudidayakan. Menurut Fitratunisa (2016) virus merupakan mikroorganisme terkecil yang tidak memiliki sel dan hanya mempunyai kode genetik saja. Virus merupakan jenis patogen yang dapat menyebabkan penyakit pada ikan dan mengakibatkan kerugian yang sangat signifikan dalam waktu yang singkat dengan tingkat kematian yang tinggi dibandingkan jenis pathogen lainnya (Sunarto et al., 2009). Virus yang menginfeksi ikan menyebabkan kerugian pada proses budidaya. VNN merupakan salah satu patogen yang menyebabkan mortalitas sampai dengan $100 \%$ pada ikan kerapu yang dibudidayakan (Sembiring et al., 2018). Infeksi VNN dapat menyerang sistem saraf pusat, retina mata serta organ reproduksi dimana virus ini 
menginfeksi hampir pada seluruh fase pertumbuhan ikan. Menurut Sudaryatma et al. (2012), penyakit VNN dapat menyerang otak sehingga menyebabkan ikan berenang berputar, mengambang dipermukaan dengan perut menghadap keatas dan pigmentasi warna yang lebih gelap pada ikan.

Ada beberapa metode deteksi patogen virus yang telah dikenal dan berkembang saat ini, antara lain PCR Konvensional, Real-Time PCR (Sembiring et al., 2018), LAMP (Yanuhar et al., 2017), ELISA (Yanuhar et al., 2017) dan Histopatologi (Yuwanita et al., 2013). Metode yang efektif dan akurat dalam deteksi virus yang sering digunakan adalah Real-time PCR (Polymerase Chain Reaction). Tetapi dalam prosesnya, metode Real-time membutuhkan biaya yang sangat mahal melihat dari bahan dan alat alat yang digunakan. Deteksi patogen menggunakan real-time PCR dapat mengeluarkan biayasebesar Rp.400.000/sampel. Hal ini yang membuat pembudidaya enggan untuk melakukan deteksi penyakit pada ikan yang dibudidayakan dan memilih untuk membiarkan ikan mati tanpa diketahui penyebabnya. Terdapat metode alternatif yang lebih murah dari Real-time PCR dan juga akurat yaitu metode histopatologi, dimana deteksi penyakit dengan histopatologi mengeluarkan biaya hanya Rp.150.000/sampel. Histopatologi merupakan prosedur pembuatan irisan jaringan untuk penentuan keberadaan (lokasi) antigen (protein target) dalam jaringan menggunakan reaksi antigen-antibodi yang diawali dengan prosedur histotenik (Damayanti, 2009 dalam Nurani et al., 2014). Pada metode histopatologi, pengamat atau peneliti penyakit dapat melihat virulensi virus dimana pada metode lain seperti Real-time PCR tidak dapat melihat hal tersebut. Virulensi merupakan tingkat keganasan virus untuk menyebabkan penyakit (Yuwanita et al., 2017). Oleh karena itu, metode diagnosis yang lain untuk peneguhan diagnosis virus seperti histopatologi perlu dilakukan agar tingkat kesehatan ikan dapat diketahui.

\section{Bahan dan Metode}

Penelitian ini dilaksanakan mulai dari tanggal 6 Agustus s/d 4 September 2020. Pengambilan sampel dilakukan di Dusun Penyambuan, Desa Jenggala, Kecamatan
Tanjung, Kabupaten Lombok Utara dan analisis molekuler histopatologi dilakukan di laboratorium kesehatan dan lingkungan BPBL Lombok, Kecamatan Sekotong Barat, Kabupaten Lombok Barat.

\section{Pengamatan dan Pengambilan Sampel Uji}

Pengambilan sampel uji dilakukan di Dusun Penyambuan, Kecamatan Tanjung, Kabupaten Lombok Utara pada tanggal 6 Agustus 2020 pukul 10.00 WITA-selesai. Sebelum melakukan pengambilan sampel uji pada KJA media budidaya ikan kerapu cantang, maka dilakukan pengamatan gejala infeksi VNN terlebih dahulu.

\section{Nekropsi Sampel Uji}

Nekropsi merupakan pengambilan organ dari sampel yang akan digunakan untuk proses uji selanjutnya. Organ yang diambil adalah bagian mata, otak, limpa dan hati karna VNN menyerang sistem saraf, hati dan juga dapat mengenai limpa. Nekropsi dilakukan langsung ditempat pengambilan sampel untuk menjaga organ tidak mengalami kerusakan.

\section{Fiksasi Sampel}

Fiksasi merupakan proses penambahan Neutral Buffer Formalin (NBF) 10\% yang bertujuan untuk memberhentikan aktifitas sel agar tidak membelah dan mencegah sel/jaringan mengalami pembusukkan.

\section{Dehidrasi, Clearing dan Impregnasi}

Tahapan dehidrasi, clearing dan impregnasi dilakukan dengan proses pengenceran alkohol menggunakan empat konsentrasi alkohol yaitu alkohol 70\%, alkohol 80\%, alkohol 96\% dan alkohol absolute (100\%). Alkohol bertingkat yang digunakan pada proses ini bertujuan untuk mengeluarkan air secara bertahap pada organ uji. Adapun tahapan dari proses dehidrasi, clearing dan impregnasi tersaji pada

Tabel 1. Estimasi waktu proses dehidrasi, clearing dan impregnasi

\begin{tabular}{cc}
\hline Proses & Waktu \\
\hline NBF 10\% & 1 Jam \\
NBF 10\% & 1 Jam \\
\hline \multicolumn{2}{c}{ Dehidrasi } \\
\hline Alkohol 70\% & 1,5 Jam \\
Alkohol 80\% & 1,5 Jam
\end{tabular}




\begin{tabular}{cc}
\hline Alkohol 96\% & 1,5 Jam \\
Alkohol 100\% & 1 Jam \\
Alkohol 100\% & 1 Jam \\
Alkohol 100\% & 1 Jam \\
\hline \multicolumn{2}{c}{ Clearing } \\
\hline Xylene & $1,5 \mathrm{Jam}$ \\
Xylene & $1,5 \mathrm{Jam}$ \\
\hline \multicolumn{3}{c}{ Impregnasi } \\
\hline Parafin & 2 Jam \\
Parafin & 2 Jam
\end{tabular}

\section{Embeding}

Embeding merupakan proses pengecoran sampel dengan parafin menggunakan mold/cetakan. Fungsi dari proses embeding adalah mencetak sampel di dalam parafin untuk memudahkan proses pemotongan.

\section{Pemotongan}

Pemotongan merupakan proses yang dilakukan sebelum pewarnaan sampel. Ukuran potongan sampel yang sudah melalui proses embeding adalah $4 \mu \mathrm{m}$ dengan menggunakan alat mikrotom. Hasil potongan sampel kemudian dimasukkan ke dalam floating bath yang berisi air dengan suhu $49^{\circ} \mathrm{C}$ yang bertujuan untuk merenggangkan hasil potongan dan meletakannya pada kaca preparat Tahapan selanjutnya yaitu kaca preparat dimasukkan ke dalam inkubator agar sampel pada preparat mengering. Penyimpanan pada inkubator dilakukan selama $\pm 2-3$ jam.

\section{Pewarnaan (Staining)}

Staining merupakan proses pewarnaan jaringan. Staining bertujuan untuk memudahkan pengamatan menggunakan mikroskop dan membedakan bagian-bagian jaringan yang akan diamati seperti inti sel, sitoplasma, dan lain-lain (Ellyawati, 2018). Proses pewarnaan sampel menggunakan pewarna hematoxilin dan eosin. Pewarna eosin pada tahapan pewarnaan digunakan untuk mewarnai sel darah atau sitoplasma pada sampel.

\section{Penempelan (Mounting)}

Penempelan (Mounting) merupakan proses penempelan coverglass pada kaca preparat dengan menggunakan cairan perekat yang disebut dengan entellan (Gambar 25a). Penggunaan coverglass bertujuan untuk melindungi kaca preparat sampel dari lensa mikroskop pada saat pengamatan.

\section{Parameter Uji}

\section{Pengamatan Kualitas Air}

Kualitas air digunakan sebagai parameter uji pada penelitian ini. Kualitas air yang diamati adalah Kecerahan, kedalaman, suhu, salinitas, DO dan $\mathrm{pH}$.

\section{Pengamatan Gejala Klinis}

Paramater uji yang digunakan untuk mendeteksi infeksi VNN adalah melihat gejala klinis dari sampel ikan. Gejala klinis tersebut dapat dilihat dari gerakan renang, warna tubuh dan nafsu makan. Jika ikan menampakkan ciri ciri terinfeksi VNN, maka ikan tersebut langsung diangkat menggunakan jaring serokan.

\section{Nekrosis}

Parameter uji selanjutnya yaitu nekrosis. Nekrosis akan terjadi ketika ikan diduga positif terinfeksi VNN dan akan terlihat pada organ otak dan mata. Nekrosis dapat terlihat di bawah mikroskop ketika proses histopatologi selesai. Jika nekrosis terjadi hampir di seluruh organ maka dikategorikan sebagai infeksi akut, sedangkan jika terjadi di beberapa tempat maka infeksi dikategorikan sebagai infeksi kronis.

\section{Hasil dan Pembahasan}

\section{Kualitas Air}

Adapun hasil pengamatan parameter kualitas air tersaji pada Tabel 2.

Tabel 2. Hasil Pengamatan Parameter Kualitas Air

\begin{tabular}{|c|c|c|}
\hline $\begin{array}{l}\text { Parameter } \\
\text { Fisika }\end{array}$ & Nilai & Standar Baku \\
\hline Kedalaman & $8,5 \mathrm{~m}$ & $\begin{array}{l}6,28 \mathrm{~m} \text { (Valentino } \\
\text { et al., 2018) }\end{array}$ \\
\hline Kecerahan & $5,5 \mathrm{~m}$ & $\begin{array}{l}\geq 5 \mathrm{~m} \text { (Valentino et } \\
\text { al., 2018) }\end{array}$ \\
\hline Suhu & $33^{\circ} \mathrm{C}$ & $\begin{array}{l}27^{\circ} \mathrm{C}-30,9^{\circ} \mathrm{C} \\
\text { (Valentino et al., } \\
\text { 2018) }\end{array}$ \\
\hline Salinitas & $32 \mathrm{ppt}$ & $\begin{array}{lll}30-33 & \mathrm{ppt} \\
\text { (Valentino et } & \text { al., } \\
2018) & & \\
\end{array}$ \\
\hline Kimia & Nilai & Standar Baku \\
\hline $\mathrm{DO}$ & $\begin{array}{l}8,35 \\
\mathrm{mg} / 1\end{array}$ & $\begin{array}{l}\geq 5 \mathrm{mg} / \mathrm{l} \text { (Valentino } \\
\text { et al., 2018) }\end{array}$ \\
\hline $\mathrm{pH}$ & 7 & $\begin{array}{l}6,0-8,2 \text { (Valentino } \\
\text { et al., 2018) }\end{array}$ \\
\hline
\end{tabular}




\section{Gejala Klinis}

Adapaun hasil pengamatan gejala klinis tersaji pada Tabel 3.

Tabel 3. Hasil Pengamatan Gejala Klinis

\begin{tabular}{|c|c|c|}
\hline No. & Sampel & Gejala Klinis \\
\hline 1. & S1 & $\begin{array}{l}\text { Berenang } \\
\text { memiliki gerakan sedikit } \\
\text { tidak terkoordinasi dan } \\
\text { warna tubuh cerah (tidak } \\
\text { pucat) }\end{array}$ \\
\hline 2. & S2 & $\begin{array}{l}\text { Gerakan renang tidak } \\
\text { beraturan } \text { (abnormal), } \\
\text { berenang menabrak ikan } \\
\text { lain, warna tubuh pucat dan } \\
\text { nafsu makan menurun. }\end{array}$ \\
\hline 3. & S3 & $\begin{array}{l}\text { Berenang berputar, warna } \\
\text { tubuh cerah dan memiliki } \\
\text { gerakan sedikit tidak } \\
\text { beraturan. }\end{array}$ \\
\hline
\end{tabular}

\section{Organ Mata}

Pengamatan sampel dilakukan dengan menggunakan mikroskop dengan perbesaran 400x. Hasil pengamatan organ mata pada penelitian dapat terlihat pada Gambar 1.

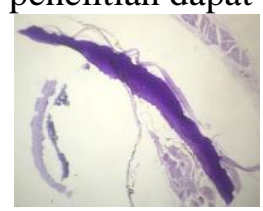

(a)

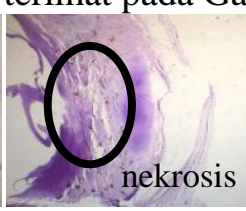

(b)

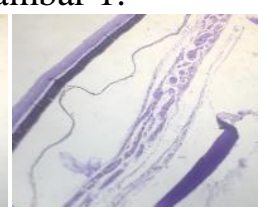

(c)
Berdasarkan hasil pengamatan, terlihat bahwa pada Gambar 1b yaitu organ mata sampel ikan ke dua mengalami nekrosis berupa adanya vakuola yang merupakan ruang kosong di dalam sel/jaringan. Sedangkan pada Gambar 1a dan Gambar 1c tidak terlihat adanya vakuola (ruang kosong) atau kerusakan pasa sel.

\section{Organ Otak}

VNN menginfeksi organ otak ikan kerapu cantang karena otak merupakan sistem saraf pusat. Adapun hasil pengamatan preparat histopatologi organ otak tersaji pada Gambar 2.

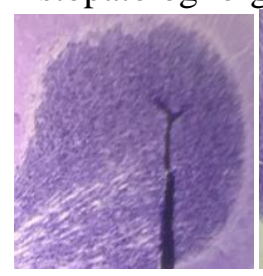

(a)

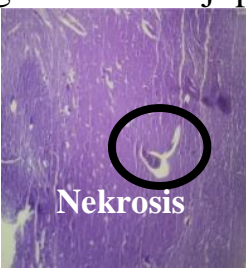

(b)

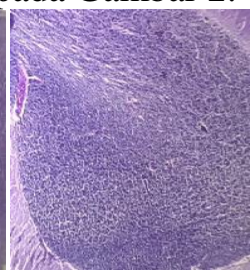

(c)
Berdasarkan hasil pengamatan mikroskop perbesaran 400x pada bagian otak ikan kerapu cantang, terlihat pada sampel jaringan otak ikan ke dua (Gambar 2b) bahwa adanya nekrosi berupa vakuola di bagian sel/jaringan otak, dimana pada sampel jaringan otak ikan pertama (Gambar 2a) dan ikan ke tiga (Gambar 2c) tidak terlihat adanya vakuola (ruang kosong), sel/jaringan yang terlihat sangat rapat.

\section{Organ Hati}

Pengamatan dilakukan pula pada jaringan hati untuk melihat ada atau tidaknya kerusakan pada sel. Adapun hasil pengamatan dari organ hati dapat dilihat pada Gambar 3.

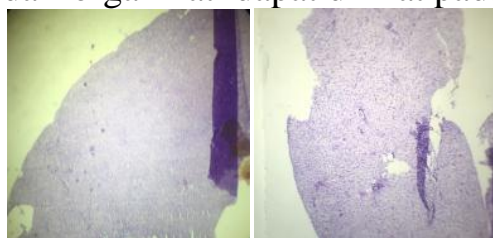

(a)

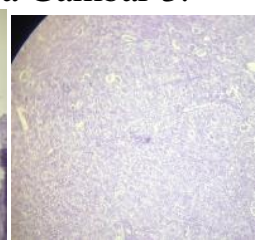

(c)
Berdasarkan hasil pengamatan pada organ hati ikan kerapu cantang dibawah mikroskop tidak terlihat adanya kerusakan baik pada sampel ikan 1 (Gambar 3a), sampel ikan 2 (Gambar 3b) dan sampel ikan 3 (Gambar 3c).

\section{Organ Limpa}

Pengamatan dilakukan pada organ limpa untuk melihat ada atau tidaknya kerusakan pada organ tersebut. Adapun hasil pengamatan dari organ limpa dapat dilihat pada Gambar 4.

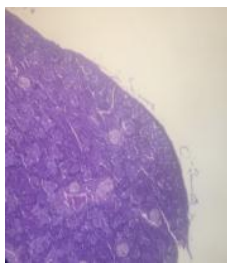

(a)

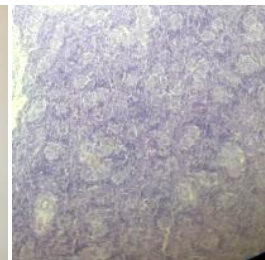

(b)

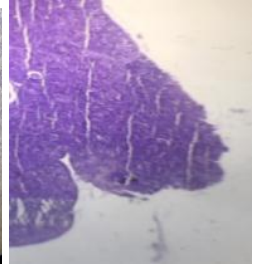

(c)
Berdasarkan hasil pengamatan sampel limpa ikan kerapu cantang (gambar 4) tidak ditemukan adanya nekrosis atau kerusakan pada jaringan limpa ikan kerapu cantang baik pada sampel 1 (Gambar 4a), sampel ikan 2 (Gambar 4b) dan sampel ikan 3 (Gambar 4c).

\section{Kualitas Air}

Kualitas Air merupakan salah satu faktor penting dalam kegiatan budidaya. Pengamatan kualitas air media budidaya ikan kerapu cantang pada KJA di Dusun Penyambuan terdapat dua 
parameter yang diamati yaitu parameter fisika dan parameter kimia. Parameter fisika pertama yang diamati adalah kedalaman dan kecerahan. Nilai kedalaman yang diperoleh pada pengamatan media budidaya adalah 8,5 meter. Sedangkan nilai kecerahan yang didapatkan adalah 5,5 meter. Menurut Radiarta (2007) dalam Valentino et al. (2018) nilai kedalaman yang optimal untuk budidaya ikan kerapu yaitu 6-28 m, sedangkan menurut Hargreves et al. (2002) dalam Valentino et al. (2018) kecerahan yang baik untuk pembesaran ikan kerapu adalah $\geq 5 \mathrm{~m}$. Maka nilai kedalaman dan kecerahan pada KJA media budidaya ikan kerapu cantang sesuai untuk budidaya.

Parameter fisika selanjutnya yang diamati adalah suhu. Suhu yang diperoleh pada pengamatan adalah $33^{\circ} \mathrm{C}$ dimana suhu ini kurang sesuai untuk media kehidupan ikan kerapu cantang. Menurut Nontji (2007) dalam Valentino et al. (2018) suhu yang baik untuk perkembangan budidaya ikan kerapu adalah $27^{\circ} \mathrm{C}-30,9^{\circ} \mathrm{C}$. Suhu air dipengaruhi oleh radiasi cahaya matahari, udara, cuaca dan lokasi (Valentino et al., 2018). Jika suhu tinggi maka kandungan DO akan menurun karena semakin tinggi suhu, kelarutan oksigen akan semakin berkurang karena tingginya kegiatan metabolisme tubuh yang mengharuskan ikan untuk menggunakan oksigen lebih banyak (Efendi, 2003). Keadaan ini dapat menyebabkan ikan menjadi stres dan mudah terkena penyakit.

Parameter selanjutnya yaitu salinitas. Salinitas yang didapatkan pada pengamatan media budidaya ikan kerau cantang di KJA adalah 32 ppt. Nilai ini merupakan tingkat salinitas yang sesuai untuk media budidaya. Menurut Evalawati et al. (2001) dalam Valentino et al. (2018) salinitas yang ideal untuk pembesaran ikan kerapu berkisar antara 30-33 ppt.

Parameter kimia pertama yang diamati adalah DO dimana DO merupakan kandungan oksigen terlarut pada perairan. Nilai DO yang didapatkan pada pengamatan media budidaya adalah 8,35 mg/l, dimana nilai tersebut merupakan nilai yang sesuai untuk media budidaya ikan kerapu. Menurut Evalawati et al. (2001) dalam Valentino et al. (2018) ikan kerapu dapat hidup layak dalam keramba jaring apung dengan konsentrasi DO $>5 \mathrm{mg} / \mathrm{l}$.
Parameter selanjutnya yaitu $\mathrm{pH}$ yang merupakan derajat keasaman suatu perairan. Nilai $\mathrm{pH}$ yang didapatkan pada pengamatan media budidaya adalah 7 dimana nilai ini merupakan nilai yang baik untuk budidaya ikan kerapu di KJA. Menurut Gufran (2010) dalam Valentino et al. (2018) nilai $\mathrm{pH}$ normal untuk budidaya di laut adalah 6,0-8,2

Penyakit pada ikan dapat disebabkan oleh tiga faktor yaitu lingkungan, inang (ikan) dan patogen (Gambar 30). Jika lingkungan dalam keadaan baik namun ikan memiliki sistem imun yang buruk, maka ikan akan mudah terkena penyakit (patogen). Lingkungan budidaya KJA pada kelompok budidaya dusun penyambuan dikategorikan dalam kadar normal untuk budidaya, tetapi ini dapat disebabkan karena sistem imun ikan yang kurang baik. Hal ini terjadi karena ikan kerapu cantang yang dibudidayakan kurang diberikan asupan pakan oleh pembudidaya dikarenakan dana yang minim dan tidak adanya bantuan pakan dari pemerintah, padahal pakan merupakan hal penting untuk memperkuat sistem imun dari ikan. Jadi dapat dikatakan bahwa ikan kerapu cantang yang terdeteksi virus VNN disebabkan karena kondisi imun ikan yang kurang baik.

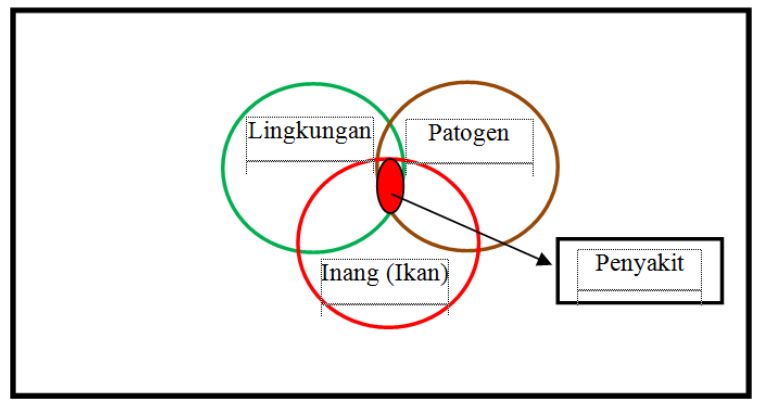

Gambar 5. Penyebab Penyakit

\section{Gejala Klinis}

Ikan yang terinfeksi VNN biasanya menunjukkan gejala yang tidak normal (abnormal). Gejala klinis umum ikan terserang VNN pada beberapa jenis ikan, antara lain, yaitu berenang tak menentu, ikan mengapung dengan perut di atas (yang disebabkan oleh pembengkakan gelembung renang), warna tubuh terlihat lebih gelap dan selera makan berkurang. Gejala ini terlihat pada sampel ikan ke dua (Gambar 11b) dimana gerakan renangnya tidak beraturan dan cenderung berenang menabrak ikan lainnya. Hal ini dapat disebabkan karena retina mata ikan mengalami kerusakan sehingga 
ikan tidak dapat melihat lingkungan sekitar. Menurut Kordi (2009) dalam Manumpil et al. (2015) Ikan yang terkena infeksi VNN biasanya memperlihatkan keadaan gangguan saraf yang berhubungan dengan vakuolisasi (kerusakan) kuat sistem saraf pusat dan retina. Selain itu menurut penuturan pembudidaya, sampel ikan kedua jarang merespon pakan yang diberikan. Hal tersebut sesuai dengan pendapat Sembiring et al. (2018) bahwa gejala umum VNN antara lain nafsu makan menurun yang meyenbabkan ikan sangat lemah, warna tubuh pucat, gerakan tidak terkoordinasi seperti berenang tidak terarah, berputar putar, hiperaktif, serta sering menghentakan kepala kepermukaan air secara sporadik.

Berbeda dengan sampel ikan kedua, sampel ikan kerapu cantang pertama (Gambar 11a) dan sampel ikan ke tiga (Gambar 11c) cenderung memiliki gerakan lebih normal, walaupun beberapa kali ikan tersebut menampakan gerakan berenang berputar putar. Hal ini dapat disebebkan karena ikan mengalami stres dan dapat pula dipengaruhi faktor lingkungan pada media budidaya. Menurut Putri et al. (2013) perubahan keadaan lingkungan yaitu kualitas air dapat mempengaruhi keseimbangan regulasi sistem saraf dan hormonal badan ikan yang dapat mengalibatkan gangguan terhadap sistem imun.

\section{Histopatologi Organ Mata}

Hasil yang diperoleh dari pengamatan histopatologi organ mata ikan kerapu cantang (Epinephelus fuscoguttatus) menunjukkan adanya jenis nekrosis atau kerusakan yang disebabkan oleh virus VNN. Sel mata sampel ikan 2 pada (Gambar 26b) mengalami vakuolisasi yaitu adanya ruang kosong pada sel. Menurut Soegianto et al. (2004) dalam Musallamah et al. (2015) Vakuolisasi ditandai dengan sel sel epitel tubulus yang terlihat dibawah mikroskop kehilangan isi selnya atau kosong dan vakuolisasi merupakan ciri khas dari serangan virus VNN. Sedangkan pada organ mata sampel ikan 1 (Gambar 26a) dan sampel ikan 3 (Gambar 26c) tidak terlihat adanya vakuolisasi. Ikan yang terinfeksi virus VNN (Viral Nervous Necrosis) memperlihatkan gangguan saraf berupa nekrosis sel dan vakuolisasi pada jaringan saraf pusat (otak) dan retina (mata) sehingga ikan yang terinfeksi terganggu keseimbangannyan (Andriyani, 2012).

Dalam jaringan mata kerapu cantang (Epinephelus fuscoguttatus) yang diduga terinfeksi VNN (Gambar 26b), kerusakan hanya terjadi di beberapa bagian, sehingga kerusakan yang terjadi termasuk dalam kerusakan yang kronis. Menurut Putri et al. (2013) apabila kerusakan terjadi hampir pada seluruh jaringan mata, maka kerusakan yang terjadi termasuk dalam kerusakan yang parah/akut sehingga mengakibatkan pelemahan pada syaraf mata ikan, selanjutnya mengakibatkan ikan menjadi buta dan berenang abnormal (menabrak dinding kolam).

Jadi jika dilihat dari kerusakan yang terjadi pada organ mata dan sebarannya maka dapat disimpulkan bahwa sampel ikan kerapu cantang 2 (Gambar 26b) diduga positif VNN dengan tingkat infeksi kronis.

\section{Histopatologi Organ Otak}

Hasil yang diperoleh dari pengamatan histopatologi organ mata ikan kerapu cantang (Epinephelus fuscoguttatus) menunjukkan bahwa infeksi VNN menyebabkan sel sel mengalami perubahan bentuk dan ukuran sel. Sel yang mengalami kerusakan (Nekrosis) menyebabkan sel di dalam otak hancur sehingga tertinggal sebagai ruang kosong yang disebut dengan vakuolisasi yang dapat terlihat pada Gambar 27b, dimana vakuolisasi tidak terlihat pada organ mata sampel ikan 1 (Gambar 27a) dan sampel ikan 3 (Gambar 27c). Hal ini diakibatkan oleh infeksi VNN melalui aliran darah dan menuju otak sehingga menimbulkan kerusakan pada jaringan (Putri et al., 2013).

Kerusakan sel dalam jaringan otak ikan kerapu cantang pada sampel ikan 2 (Gambar 27b) terjadi di beberapa bagian otak sehingga dapat dikatakan bahwa kerusakan jaringan dalam otak ikan kerapu cantang (Epinephelus fuscoguttatus) adalah kronis. Menurut Utama et al. (2019) tingkat kronis merupakan tingkatan penyakit yang mengakibatkan kerusakan saraf dan organ, berlangsung dalam kurun waktu yang lama (selama bertahun tahun) sehingga tingkat infeksi kronis biasanya terjadi pada ikan yang sudah berumur dewasa atau yang siap panen.

Serangan VNN lebih ganas pada ikan yang masih muda terutama pada fase larva dan benih dimana pada saat fase tersebut ikan kerapu 
sangat sensitif karena kekebalan tubuhnya masih lemah, sehingga keadaan ini mengakibatkan serangan VNN jauh lebih akut (Bimami, 2009 dalam Putri et al., 2013).

Jadi jika dilihat dari kerusakan yang terjadi pada organ otak dan sebarannya maka dapat disimpulkan bahwa sampel ikan kerapu cantang 2 (Gambar 26b) diduga positif VNN dengan tingkat infeksi kronis.

\section{Histopatologi Organ Hati}

Hasil yang diperoleh dari pengamatan histopatologi organ hati ikan kerapu cantang (Epinephelus fuscoguttatus) menunjukkan bahwa tidak adanya kerusakan (nekrosis) pada ketiga sampel tersebut dan organ terlihat rapat. Pengamatan jaringan hati biasanya dilakukan untuk mengetahui ada atau tidaknya infeksi iridovirus, karena gejala klinis dari virus VNN dan Iridovirus hampir sama tetapi menyerang organ yang berbeda, dimana menurut Mahardika et al. (2003) infeksi iridovirus biasanya menyerang organ hati, limpa dan ginjal. Adapun gejala klinis dari infeksi Iridovirus antara lain warna tubuh ikan gelap, insang pucat, nafsu makan turun, serta pergerakan renang yang lemah dan tidak terkoordinasi (Sembiring et al., 2018).

Jadi jika dilihat dari tanda tanda pengamatan mikroskop organ hati ikan kerapu cantang yang tidak diemukan kerusakan (nekrosis), maka dapat disimpulkan bahwa tidak terdeteksi serangan VNN pada organ hati.

\section{Histopatologi Organ Limpa}

Hasil yang diperoleh dari pengamatan organ limpa dari ikan kerapu cantang menunjukkan tidak adanya kerusakan (nekrosis) pada ketiga sampel sama seperti organ hati dan sampel yang diamati terlihat sangat rapat. Sama halnya dengan organ hati, limpa digunakan untuk deteksi infeksi iridovirus. Infeksi iridovirus ini secara anatomi ditandai dengan pembengkakan pada organ limpa (spleenomegally) dan secara histopatologi ditandai adanya sel-sel yang membesar (heteromorphic ballon cells) (Danayadol et al., 1997 dalam Mahardika et al., 2003).

Jadi jika dilihat dari tanda tanda pengamatan mikroskop organ limpa ikan kerapu cantang yang tidak diemukan kerusakan (nekrosis), maka dapat disimpulkan bahwa tidak terdeteksi serangan VNN pada organ limpa.

\section{Kesimpulan}

Hasil pengamatan menggunakan metode histopatologi dan pada penelitian ini ditemukan pada sampel ikan kerapu cantang (Epinephelus fuscoguttatus) ke dua (S2) dari kelompok budidaya Keramba Jaring Apung (KJA) di Dusun Penyambuan Kecamatan Tanjung, Kabupaten Lombok Utara dan diduga positif terinfeksi virus VNN (Viral Nervous Necrosis) dengan ciri utama pada nekrosis yang berupa vakuola pada organ mata dan otak dalam tingkat infeksi kronis.

\section{Ucapan Terima Kasih}

Ucapan terimakasih kepada Program Studi Buiddaya Perairan dan Balai Perikanan Budidaya Laut (BPBL) Lombok yang sudah membantu dalam proses penelitian.

\section{Referensi}

Adi, A.A.M. (2013). Teknik Imunostaining. Panduan Praktikum Histopatologi Fakultas Kedokteran Hewan Univeristas Udayana.

Afrianto, E., E. Liviawaty, \& Z. Jamaris (2015). Penyakit Ikan. Penebar Swadaya. Jakarta.Tebal buku: 100 halaman.

Andriyani, W.M. (2012). Uji Kemampuan Kandidat Vaksin DNA Viral Nervous Necrosis dalam Menginduksi Antibodi pada Ikan Kerapu Tikus (Cromileptes altivelis). Skripsi. Pascasarjana Mikrobiologi Medik: Institut Pertanian Bogor. $52 \mathrm{hlm}$.

Bestari, B.K., \& K.W. Dewi (2016). Penyakit Kronis Lebih Dari Satu Menimbulkan Peningkatan Perasaan Cemas pada Lansia Di Keccamatan Cibinong. Jurnal Keperawatan Indonesia, 19 (1): 49-54. http://www.jki.ui.ac.id/index.php/jki/artic le/view/433 
Ellyawati (2018). Penentuan Waktu Yang Tepat Pada Proses Staining Dalam Pembuatan Preparat Histologis Hati. Jurnal Perikanan Indonesia. 1 (1): 28-30.

Gupta, E., P. Bhalla, N. Khurana \& T.Singh. 2009. Histopathology for the diagnosisof infectious diseases. Indian Journal of Medical Microbiology. 2 (7): 100-106.

Isdaddiyanto S. (2015). Efek Chitosan pada Histopatologi Aorta Tikus Putih yang Diberi Pakan Lemak Tinggi. Jurnal Buletin Anatomi dan Fisiologi. 13 (1): 5768. http://eprints.undip.ac.id/45894/

Iswara, A., \& W. Tri. (2017). Pengaruh Variasi Waktu Clearing Terhadap Kualitas Sediaan Awetan Permanen Ctenocephalides felis. Jurnal Labora Medika. $\quad 1 \quad$ (1): $12-15$. https://core.ac.uk/download/pdf/2340379 $\underline{15 . p d f}$

Julianti (2017). Teknik Histopatologi dalam deteksi Virus Iridovirus pada Ikan Kerapu Macan (Ephinephelus fusgottatus). Jurnal Perikanan Indonesia. 2 (1): 45-48.

Kementrian Kelautan \& Perikanan (2018). Potensi Usaha dan Peluang Investasi Kelautan dan Perikanan. $87 \mathrm{hlm}$.

Lestari, A.T., \& P.E. Sudaryatma (2014). Studi Imunohistokimia Darah dan Suspensi Organ Kerapu Macan (Epinephelus fuscoguttatus) yang Diinfeksi Virus Isolat Lapang Penyebab Viral Nervous Necrosis. Jurnal Sain Veteriner. 32 (1): 85-92.

Lestari, A., \& P. Eka (2014). Studi Imunositokimia Darah dan Suspensi Organ Kerapu Macan (Epinephelus fuscoguttatus) yang Diinfeksi Virus Isolat Lapang Penyebab Viral Nervous Necrosis. Jurnal Sains Veterner. 32 (1): 85-92.

Mahardika, K., I. Koesharyani, A. Prijono., \& K. Yuasa (2003). Infeksi Iridovirus Pada Induk Kerapu Lumpur (Epinephelus Coioidesl). Jurnal Penelitian Perikanan Indonesia. 9 (1): 49-54.
Mahardika, K., K. Isti., P. Agus, \& Y. Kei. (2003). Infeksi Iridovirus Pada Induk Kerapu Lumpur (Ephinephelus coiodes). Jurnal Penelitian Perikanan Indonesia. 9 (1): 49-54. http://ejournalbalitbang.kkp.go.id/index.php/jppi/article/ view/4531/3930

Mahardika, K., Zafran, \& R. Melianawati (2005). Monitoring Kejadian Infeksi Viral Nervous Necrosis (VNN) pada Larva dan Yuwana Ikan Kerapu dan Kakap Merah Pada Pemeliharaan dengan Sistem Tertutup. Jurnal Penelitian Perikanan Indonesia. 11 (7): 25-32.

Manan, A., \& Pratiwi, H. C. (2015). Teknik Dasar Histologi pada Ikan Gurami (Osphronemus gouramy) [The Basic Histology Technique of Gouramy Fish (Osphronemus gourami)]. Jurnal Ilmiah Perikanan dan Kelautan, 7(2), 153-158. https://e-

journal.unair.ac.id/JIPK/article/viewFile/1 $\underline{1199 / 6290}$

Mariskha, R.P., \& A. Nurlita (2012). Aspek Reproduksi Ikan Kerapu Macan (Epinephelus sexfasciatus) di Perairan Glondonggede Tuban. Jurnal Sains dan Seni ITS. 1. (27): 142-147. http://ejurnal.its.ac.id/index.php/sains sen i/article/view/774

Muntiha, M. (2001). Teknik Pembuatan Preparat Histopatologi dari Jaringan Hewan dengan Pewarnaan Hematoksilin dan Eosin (H\&E). Temu teknis Fungsional Non Peneliti. Halaman: 156-163.

Nurani, F.R., H. Suprapto, \& Suwarno (2014). Identifikasi Koi Herpes Virus (KHV) Pada Dosis yang Berbeda dengan Metode Imunohistokimia Streptavidin Biotin Pada Ikan Nila (Oreochromis niloticus). Jurnal Ilmiah Perikanan dan Kelautan. 6 (2): 109-115.

Pratiwi, H.C., \& M. Abdul (2015). Teknik Dasar Histologi Pada Ikan Gurami (Osphronemus 
Gouramy). Jurnal Ilmiah Perikanan dan Kelautan. 7 (2): 153-157.

Putri, R.R., Y. Uun., \& A.S. Maizar (2013). Perubahan Struktur Jaringan Mata dan Otak Pada Larva Ikan Kerapu Tikus (Cromileptes altivelis) yang Terinfeksi Viral Nervous Necrosis (VNN) dengan Pemeriksaan Scanning Electron Microscope (SEM). MSPi Student Journal. 1 (1):1-10. file:///C:/Users/ASUS/Downloads/1-3-1$\underline{\text { PB.pdf }}$

Putri, R.R., U. Yanuhar, \& A.M. Suryanto (2013). Perubahan Struktur Jaringan Mata dan Otak pada Larva Ikan Kerapu Tikus (Cromileptes altivelis) yang Terinfeksi Viral Nervous Necrosis (VNN) dengan Pemeriksaan Scanning Elektron Microscope (SEM). MSPiSTUDENT Journal. $\quad 1 \quad$ (1): $\quad 35-42$. http://mspi.studentjournal.ub.ac.id/index. $\mathrm{php} / \mathrm{mspi} /$ article/view/1

Sari, S. \& D.A. Wardiyanto (2014). Profil Histopatologi Kerapu Tikus (Cromileptes Altivelis) Yang Distimulasi Jintan Hitam (Nigella Sativa) dan Diinfeksi Viral Nervous Necrosis (VNN). Jurnal Ilmu Perikanan dan Sumberdaya Perairan. 4 (2): 208-212.

Sembiring, S.B.M., S.W. Gigih, M. Ketut, W. Zeny, \& Haryanti (2018). Prevalensi Infeksi Viral Nervous Necrosis (VNN) dan Iridovirus pada Hetcheri dan Budidaya Ikan Laut. Media Akuakultur. 13 (2): 8390.

Sembiring, S. B. M., S.W Gigih, Ketut M. Zony W, \& Haryanti. 2018. Prevalensi Infeksi Viral Nervous Necrosis (VNN) pada Hatcheri dan Budidaya Ikan Laut. Jurnal Media Akuakultur. 13 (2): 83-90. http://ejournal-

balitbang.kkp.go.id/index.php/ma/article/ view/6933

Wahyuni, S., Windarti, \& R.M. Putra (2015). Studi Komparatif Jaringan Insang dan Ginjal Ikan Gabus (Channa striata,
BLOCH 1793). Jurnal Perikanan Indonesia. 8 (2): 160-167.

Widyanto, Y. (2014). Pengaruh Penambahan Jintan Hitam (Nigella sativa) pada Pakan Terhadap Gambaran Darah dan Kelulusan Hidup Ikan Kerapu Cantang (Ephinephelus sp.) Skripsi. UMM. Malang. $56 \mathrm{hlm}$.

Yuwanita, R.., R.B. Nanik, \& F.E.P Handian (2018). Pengaruh Dunaliella Salina Terhadap Polimorfonuklear Leukosit Ikan Kerapu Cantang (Epinephelus fuscoguttatus $x$ Epinephelus lanceolatus) Yang Diinfeksi Viral Nervous Necrosis (VNN). 